\title{
ESTADO ATUAL DO PROBLEMA DA POLIOMIELITE NO MUNICÍPIO DE SÃO PAULO (1)
}

Estudo do problema da poliomielite no municipio de São Paulo, desde 1933 até 1967, dando ênfase ao periodo de 1962 a 1967 , quando é analisada a relação entre a variação da incidência da doença em tela e as campanhas de vacinação em massa com a vacina de virus vivos atenuados, então relizadas. Com base nos dados apresentados, conclue-se que no ano de $196 \%$, em que o coeficiente de morbidade por 100.000 habitantes por poliomielite foi de 0,6 , foi possivel se conseguir o contrôle dessa doença em nossa Capital.

Em trabalho anterior (BARBosa ${ }^{1}, 1963$ ) estudamos a epidemiologia da poliomie. lite no município de São Paulo. Pude. mos então demonstrar que a tendência desta doença, durante o intervalo de tem. po de 1933 a 1960 , podia ser dividida em dois períodos: o primeiro, cóm cifras moderadamente decrescentes, terminando por uma queda mais acentuada em 1949 e 1950; o segundo, subindo acentuadamente até 1960 (Fig. 1). Nesta mesma Figura, também, é possível evidenciar três picos epidêmicos nos anos de 1939 , 1953 e 1960, cujos coeficientes de morbidade por 100.000 habitantes foram igụais a $3,1,7,7$ e 20,0 , respectivamente (Tabela 1).

Ainda no mesmo estudo, partindo novamente da observação da Figura 1 , dissemos que: $a$ ) a morbidade por poliomielite de 1954 a 1960 mostrou-se contìnuamente ascensional e com oscilações muito pequenas; $b$ ) os valores desta morbidade, a partir de 1955, situaram-se em niveis superiores a 3 ou 4 casos por 100.000 habitantes; $c$ ) estabeleceu-se uma associação inversa entre a morbida- de por poliomielite e a mortalidade infantil; $d$ ) esta mortalidade infantil, a partir de 1957, sofreu uma queda para 75 ou menos por 1.000 nascidos vivos.

Em vista do exposto no item $a$ fomos levados a sugerir que a incidência da virose vinha experimentando acréscimos aproximadamente iguais de ano para ano, indicativos de sensível alteração na estrutura epidemiológica da Capital, nunca dantes observada, que, a exemplo do verificado em outras partes do mundo, se tornava progressivamente favorável à ocorrência da doença entre nós. Com base nos itens $b, c$ e $d$ tivemos oportunidade de apontar a presença, entre nós, dos sinais premonitórios da ascensão da incidência da moléstia a valores sem precedentes na nossa Capital. Estes fatos ensejaram-nos a chamar a atenção para a implantação, desde 1955, de um nôvo padrão epidemiológico da poliomielite entre nós - o potencialmente epidêmico - e, também, para o sinal de alerta, desde 1957, da iminência dos primeiros surtos epidêmicos extensos e severos na nossa Capital.

Recebido para publicação em 20-2-1968.

(1) Da Cadeira de Epidemiologia da Faculdade de Higiene e Saúde Pública da USP e do Serviço de Centros de Saúde da Capital da Secretaria da Saúde Pública do Govêrno do Estado de São Paulo. 
BARBosa, V. - Estado atual do problema da poliomielite no município de såo Paulo. Rev. Saúde públ., S. Paulo, 2(1):68-80, jun. 1968.

TA BELA 1

Morbidade por poliomielite no municipio de São Paulo - 1933 a 1967 (Coeficientes por 100.000 habitantes)

\begin{tabular}{|c|c|c|}
\hline Anos & Casos & Coeficientes \\
\hline 1933 & 6 & 0,6 \\
\hline 1934 & 6 & 0,6 \\
\hline 1935 & 4 & 0,4 \\
\hline 1936 & 13 & 1,2 \\
\hline 1937 & 24 & 2,1 \\
\hline 1938 & 7 & 0,6 \\
\hline 1939 & 39 & 3,1 \\
\hline 1940 & 18 & 1,4 \\
\hline 1941 & 13 & 0,9 \\
\hline 1942 & 29 & 2,0 \\
\hline 1943 & 14 & 0,9 \\
\hline 1944 & $\mathbf{1 7}$ & 1,1 \\
\hline 1945 & 26 & 1,5 \\
\hline 1946 & 10 & 0,6 \\
\hline 1947 & 30 & 1,6 \\
\hline 1948 & 12 & 0,6 \\
\hline 1949 & 4 & 0,2 \\
\hline 1950 & 3 & 0,1 \\
\hline 1951 & 14 & 0,6 \\
\hline 1952 & 29 & 1,2 \\
\hline 1953 & 197 & 7,7 \\
\hline 1954 & 72 & 2,7 \\
\hline 1955 & 133 & 4,5 \\
\hline 1956 & 243 & 7,8 \\
\hline 1957 & 316 & 9,5 \\
\hline 1958 & 416 & 11,8 \\
\hline 1959 & 451 & 12,1 \\
\hline 1960 & 794 & 20,0 \\
\hline 1961 & 469 & 11,1 \\
\hline 1962 & 180 & 4,4 \\
\hline 1963 & 517 & 11,9 \\
\hline 1964 & 344 & 7,5 \\
\hline 1965 & 356 & 7,4 \\
\hline 1966 & 223 & 4,3 \\
\hline 1967 & 32 & 0,6 \\
\hline
\end{tabular}

Fonte: Secção de Epidemiologia e Profilaxia Gerais da Secretaria da Saúde Pública do Estado de São Paulo.

A implantação dêste nôvo padrão epidemiológico da poliomielite em nossa metrópole, em substituição ao endêmico anteriormente existente, colocou-a entre as comunidades nas quais a poliomielite paralítica constitui um problema sanitário, devendo nelas, por isso, segundo MoRAES $^{2}$ (1960), ser empreendida a vacinação antipoliomielítica em massa. Com efeito, sendo êste padrão de caráter possivelmente irreversível, a nossa comuni- dade estaria então, por analogia com o ocorrido em outras áreas geográficas (PAUL ${ }^{3}, 1958$ e PAYNe $\left.{ }^{4}, 1955\right)$, exposta ao grave risco de ser atingida por epidemias que poderiam ser mesmo severas se, o quanto antes, essa vacinação não fôsse feita.

A êste respeito, em diferentes oportunidades, entre as quais se inclui a palestra sôbre "Vacinação contra a poliomielite no município de São Paulo", que fizemos no Departamento de Pediatria da Associação Paulista de Medicina, no dia 12 de fevereiro de 1960, focalizamos aquêles` aspectos. Nessa ocasiāo; poucos meses antes do surto epidêmico da virose ocorrido de agôsto a dezembro dêsse ano, alertamos nossas autoridades sanitárias sôbre o risco acima citado e' também, encarecemos a necessidade de se iniciar a vacinação em massa de nossa população com a vacina Sabin.

Nessas condições, não fôra a ação oportuna e efetiva da vacinação de nossa população com vírus "atenuados (vacina Sabin) no ano de 1962, modificando a estrutura epidemiológica da Capital no sentido de torná-la desfavorável à transmissão e à ocorrência- da paralisia infan; til, tudo fazia prever que dias amargos estavam reservados à nossa população. Dissemos oportuna porque, em 1960, como vimos, já tivemos uma epidemia sem precedentes na nossa Capital, com 794 casos notificados da doença. Além disso, a incidência da doença no ano de 1961 ainda foi alta, isto é, de 11,1 por 100.000 habitantes, correspondente a 469 casos, ao passo que no ano da vacinação, em 1962, êste coeficiente baixou para 4,4, correspondente a 180 casos. Por fim, sòmente depois de junho, quando da segunda dose, o efeito da vacina se fêz sentir realmente pois, nos meses subseqüentes dêste ano, o número de casos foi de $5,7,10,13$ e 13, comparados com 17, 16, 30, 53 e 61 no ano anterior:

Portanto, em virtude de tudo que foi exposto, no município de São Paulo em 
BARBOSA, V. - Estado atual do problema da poliomielite no municiplo de São Paulo. Rev. Saúde públ., S. Paulo, 2(1):68-80, jun. 1968.

1962, graças a imunoprofilaxia ativa artificial da sua população suscetível com a vacina de vírus atenuados, então efetuada, estabeleceram-se as condições epidemiológicas iniciais eminentemente favoráveis ao contrôle e, quiçá, à erradicação da poliomielite. Nascia assim a esperança de, para o futuro, pràticamente não virem mais as nossas crianças padecerem da terrivel moléstia que, com sua marca permanente em certa proporção dos atingidos por ela, produz uma para. lisia flácida de maior ou menor extensão, e de localização variável.

Tudo estava então preparado para que aquela esperança, posteriormente, se transformasse efetivamente em auspiciosa realidade. Mas, para que tal viesse a se concretizar na prática, em tôda a sua plenitude, era preciso que as nossas autoridades sanitárias, depois da segunda dose da vacina aplicada em 1962, tivessem continuado a vacinar em massa a nossa população, visando, é claro, a cobertura integral dos suscetíveis à doença. $E$ essas campanhas em massa subseqüentes, por sua vez, teriam um duplo objetive que, se satisfeitos, iriam introduzir certos elementos na estrutura epidemiológica da Capital, tornando-a seguramente imprópria para a ocorrência da doença.

0 primeiro dêsses objetivos seria o de completar a imunidade das crianças vacinadas nas duas primeiras campanhas em massa antes mencionadas. Para isso, deveriam elas receber uma terceira dose básica, seguida de uma dose de refôrço da vacina; aquela com um intervalo de

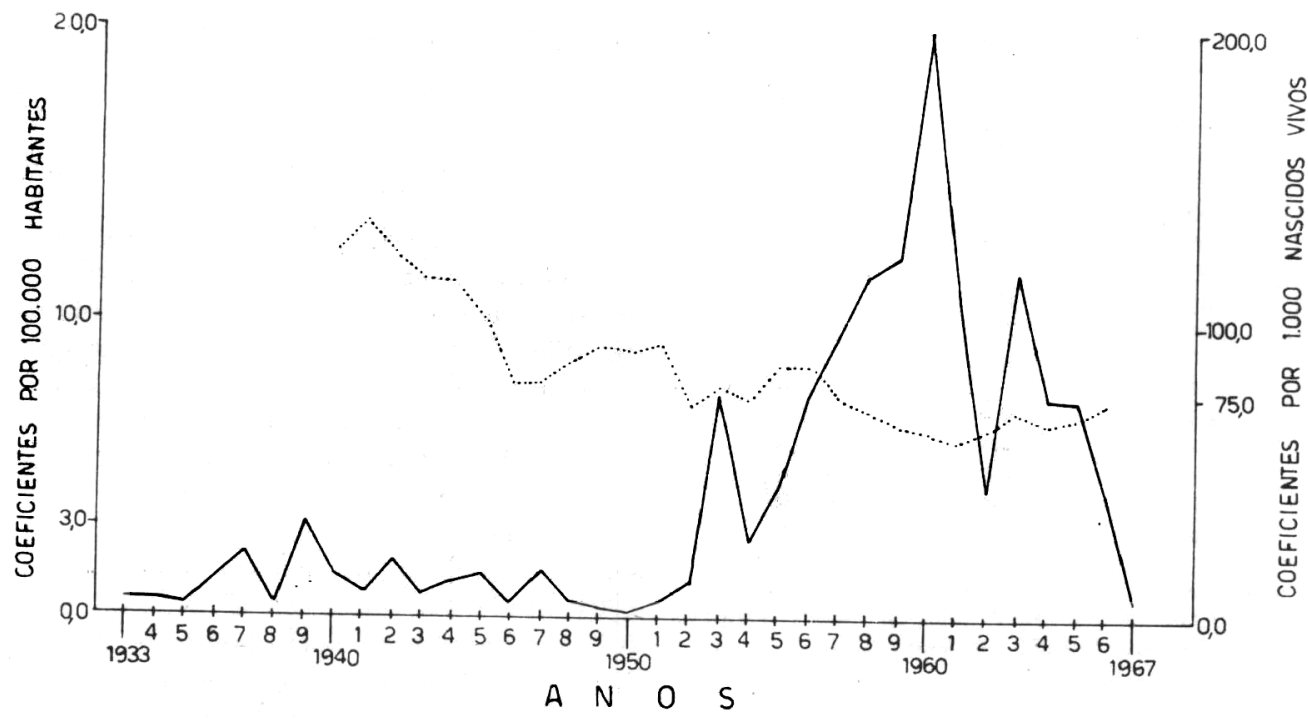

\section{LEGENDA:}

- POLIOMIELITE

MORTALIOADE INFANTIL

Eronte: Morbidade por Poliomielite Paralitica _- Secção de Epldemiologia e Profilaxia Gerals, da Secretaria da Saúde Pública do Estado de Săo Paulo. Mortalidade Infantil - Departamento de Estatística do Estado de São Paulo.

Fig. 1 - Morbidade por poliomielite paralitica e mortalidade infantil no municiplo de São Paulo - 1933 a 1967 
BARBOSA, V. - Estado atual do problema da poliomielite no municipio de São Paulo. Rev. Sauide pübl., S. Paulo, 2(1):68-80, jun. 1968.

duas a quatro semanas da segunda campanha e, esta última, entre seis a oito meses depois da terceira dose básica, de conformidade com o recomendado pelo esquema de vacinação completo contra a poliomielite pela vacina Sabin. O segundo objetivo, a seu turno, seria o da imunização também com quatro doses, em esquema semelhante, dos novos suscetíveis que fossem surgindo na Capital. Entre êstes últimos seriam incluídos os nascidos vivos em nossa comunidade nessa época, assim como os transmigrantes nela fixados, após junho de 1962, provenientes de outras áreas.

Isto posto, cabe agora perguntar: qual a parcela etária de nossa população que deveria receber os benefícios dessas vacinações em massa com a vacina Sabin? Evidentemente aquela em que, devido a grande suscetibilidade de seus membros à poliomielite, condicionada por características próprias da estrutura epidemiológica do município em relação à esta doença, vinha ocorrendo a grande maioria dos casos de paralisia infantil nele notificados. A Tabela 2, que nos mostra a distribuição etária dos casos de poliomielite paralítica notificados na nossa $\mathrm{Ca}$ pital, de 1954 a 1959 , é bastante elucidativa neste sentido: a grupo etário de 0-4 anos inclusive, pois, a êste grupo pertenciam $94,7 \% \%$ dos casos notificados.

Barbosa ${ }^{1}$ (1963), porém, verificou que as informaçôes de que dispomos sôbre a distribuição etária da poliomielite em nosso meio, através dos dados oficiais, não traduzem inteiramente a realidade. Há um grande número de casos que não são notificados e não chegam ao conhecimento das autoridades. Estes casos são justamente os que ocorrem nas parcelas mais favorecidas da população. Neles, ao invés dos $94,7 \%$ correspondentes ao grupo etário de $0-4$ anos inclusive, apenas $86,41 \%$ é que, na verdade, pertencem ao referido grupo de idade (Tabela 2). Isto quer dizer que, como já aconteceu em outros países, já se instalara em nosso município a tendência

TA BELA 2

Distribuicão dos casos de poliomielite paralítica oficiais (1) e registrados pelos médicos particulares (2), segundo os grupos etários, no municipio de Săo Paulo. - 1954 a 1959 (percentagens médias)

\begin{tabular}{|c|c|c|c|c|}
\hline \multirow{2}{*}{$\begin{array}{c}\text { Idade } \\
\text { (em anos) }\end{array}$} & \multicolumn{2}{|c|}{ Oficiais } & \multicolumn{2}{|c|}{ Médicos particulares } \\
\hline & Casos & $\%$ & Casos & $\%$ \\
\hline Menos de 1 & 619 & $\mathbf{3 7 , 8}$ & 121 & 26,1 \\
\hline 1 & 594 & 36,3 & 132 & 28,5 \\
\hline 2 & 235 & 14,4 & 80 & 17,3 \\
\hline 3 & 74 & 4,5 & 38 & 8,2 \\
\hline 4 & 27 & 1,7 & 29 & 6,3 \\
\hline $01-5$ & 1.549 & 94,7 & 400 & 86,4 \\
\hline $5 i-10$ & 49 & 3,0 & 43 & 9,3 \\
\hline $10-15$ & 15 & 0,9 & 12 & 2,6 \\
\hline 15 e + & 23 & 1,4 & 8 & 1,7 \\
\hline Ignorada & - & - & - & - \\
\hline Total & 1.636 & 100,0 & 463 & 100,0 \\
\hline
\end{tabular}

(1) Dados da Secção de Epidemlologia e Profllaxia Gerais da Secretaria da Saúde Pública do Estado de São Paulo, pela data dos primeiros sintomas.

(2) Dados do registro dos médicos particulares da Capital, pela data dos primeiros sintomas. 
BARbosa, V. - Estado atual do problema da poliomielite no município de São Paulo. Rev. Saúde públ., S. Paulo, 2(1):68-80, jun. 1968.

de um deslocamento da distribuição etária da poliomielite para idades mais avançadas - no caso de 5 a 9 anos inclusive - a qual iria se efetivar se, em tempo, não fôssem vacinadas em massa as crianças destas idades.

Por conseguinte, todos êstes fatos nos levam a admitir que as nossas autoridades, por exemplo, poderiam ter programado para a continuidade da vacinação em massa contra a poliomielite no município de São Paulo, posteriormente à junho de 1962, o esquema que apresentamos na Tabela 3 . Nessas campanhas, com exceção das de outubro de 1962, junho de 1963 e junho de 1964, em que poderiam ter sido vacinadas as crianças até 9 anos de idade inclusive, seriam imunizadas apenas as crianças até 4 anos de idade inclusive. Além disso, devido a melhoria da técnica de conservação da vacina, a partir do início de 1964, que a tornou viável por 30 dias - e até mesmo seis meses na geladeira comum - o uso diário e rotineiro da vacina Sabin pelas nossas unidades sanitárias já poderia ter sido introduzido entre nós. E êste nôvo processo de aplicação coletiva da vacina poderia ter sido aproveitado para a correção das falhas verificadas nas campanhas anteriores, sobretudo nas das vacinações das crianças de menos de 2 anos inclusive; isto porque são estas últimas as que mais necessitam ser completamente vacinadas, entre nós, face ao fato de que nelas, conforme nos mostra a Tabela 2, é que ocorre acima de $85 \%$ e $95 \%$, respectivamente, do total de casos da doença em tôdas as idades e no grupo etário de 0-5 anos incompletos, notificados em nossa Capital.

Se isso tudo tivesse sido feito, as nossas autoridades sanitárias no fim do ano de 1964, mui provàvelmente, já. teriam dado cobertura vacinal integral a mais de $75 \%$ dos suscetíveis à paralisia infantil existentes na Capital. E, com isso, teriam conseguido estabelecer então o contrôle da doença, com o seu retôrno à fase endêmica, caracterizada pela queda de sua freqüência a valores iguais ou inferiores a 3 casos por 100.000 habitantes.

Infortunadamente, porém, tal não se verificou, conforme podemos depreender pelo exame da Figura 1. Este gráfico, com efeito, nos mostra que os coeficientes de morbidade por poliomielite na Capital, desde 1962 até o início de 1967, ainda se mantiveram em níveis sempre superiores a 3 casos por 100.000 habitantes, a despeito das oito campanhas de vacinação em massa e das imunizações de rotina realizadas, umas e outras, no período de 1962 a 1966 (Tabela 4). Isto, em outras palavras, quer dizer que

T A B ELA $\mathbf{3}$

Esquema recomendado para a cronologia das campanhas de vacinação em massa antipoliomielítica no município de São Paulo, a partir de janeiro de 1962

\begin{tabular}{|c|c|c|c|}
\hline \multirow{2}{*}{$\begin{array}{l}\text { Vacinados com } \\
\text { a } 1 .^{a} \text { dose na } \\
\text { campanha de: }\end{array}$} & \multicolumn{3}{|c|}{ Deveriam rece ber } \\
\hline & $\begin{array}{l}\text { a } 2 .^{a} \text { dose na } \\
\text { campanha de: }\end{array}$ & $\begin{array}{l}\text { a } 3.0^{a} \text { dose na } \\
\text { campanha de: }\end{array}$ & $\begin{array}{l}\text { a dose de reforrso } \\
\text { campanha de: }\end{array}$ \\
\hline 1962 - Janeiro & 1962 - Junho & 1962 - Outubro & 1963 - Junho \\
\hline 1962 - Junho & 1962 - Outubro & 1963 - Fevereiro & 1963 - Outubro \\
\hline 1962 - Outubro & 1963 - Fevereiro & 1963 - Junho & 1964 - Fevereiro \\
\hline 1963 - Fevereiro & 1963 - Junho & 1963 - Outubro & 1964 - Junho \\
\hline 1963 - Junho & 1963 - Outubro & 1964 - Fevereiro & 1964 - Outubro \\
\hline
\end{tabular}


BARBoSA, V. - Estado atual do problema da pollomielite no município de Săo Paulo. Fiev. Saúde públ., S. Paulo, 2(1):68-80, jun. 1968.

ao começarmos o ano de 1967, ao invés de termos colocado a poliomielite sob contrôle, esta última, na verdade, ainda se mantinha em fase potencialmente epidêmica.

E porque isto aconteceu? Porque as nossas autoridades, apesar de terem dispendido muitos esforços, tempo e dinheiro na execução das vacinações contra a poliomielite, não tinham conseguido, até o fim do ano de 1966, libertar as nossas crianças do perigo representado pela ocorrência provável de surtos severos da doença? Julgamos que a resposta a esta pergunta deve ser procurada na análise da Figura 2, em que apresentamos os coeficientes semestrais por 100.000 habi- tantes dos casos da moléstia notificados na Capital de 1954 a 1967, bem como a sua relação com a cronologia das campanhas de vacinação em massa antipoliomielítica realmente efetuadas entre nós de 1962 a 1967 , já apresentadas, em detalhes, na Tabela 4.

Inicialmente, na Figura 2, vemos que nos anos de 1961 e 1962, considerando-se os coeficientes semestrais, houve progressiva e acentuada queda da morbidade por poliomielite paralítica na Capital. Esta queda, se analisada em térmos da comparação dos coeficientes dêsses anos com o do ano de 1960 (Tabela 1), tomado como índice igual a 100 , foi respectivamente de $45,5 \%$ e $78,1 \%$ (Fig. 1 ).

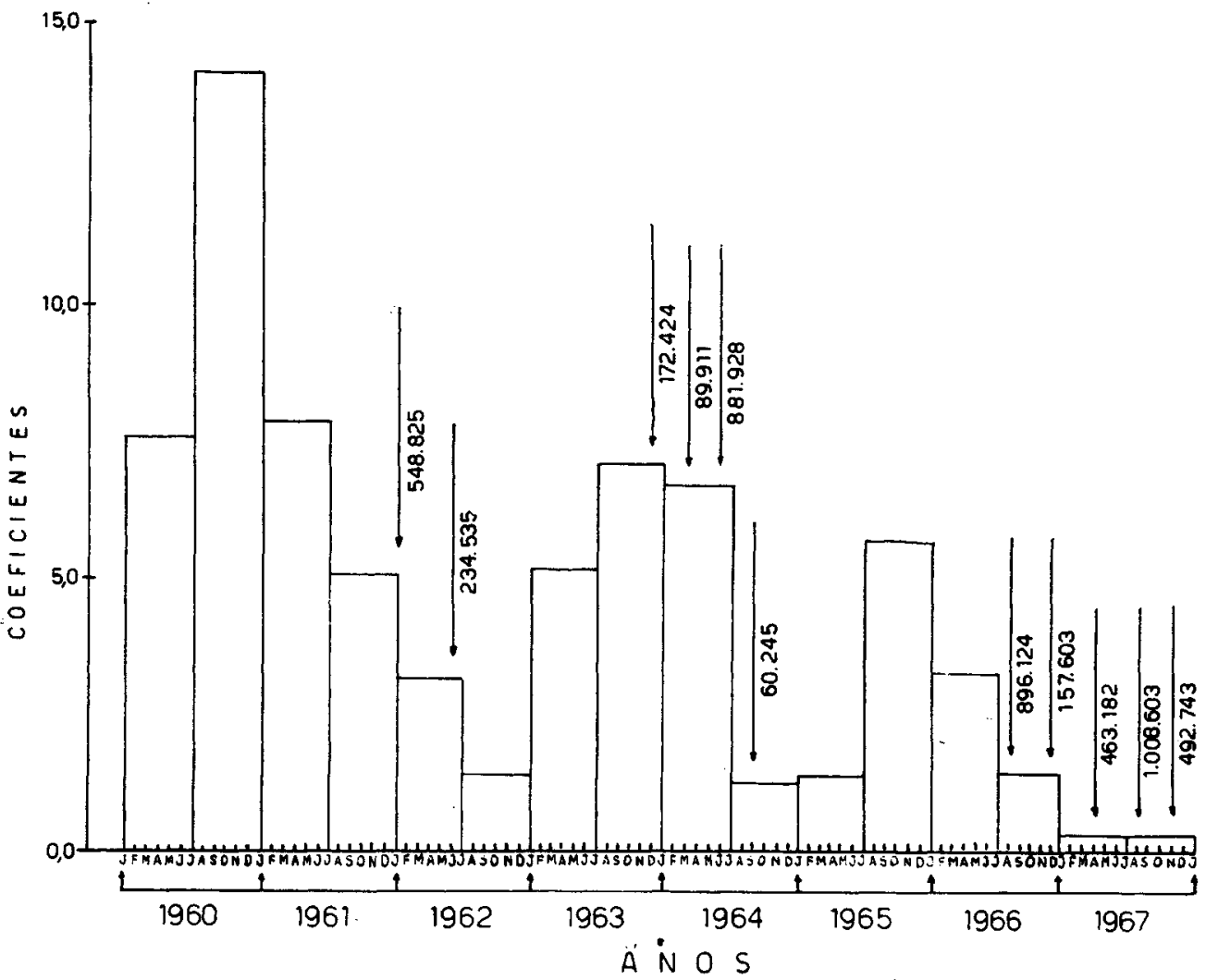

Fonte: Secção de Epidemiologia e Profilaxia Gerais da Secretaria da Saúde Pública do Estado de São Paulo.

Flg. 2 - Morbidade por poliomlelite paralitica no município de São Paulo. - 1960 a 1967. (Coeficientes por 100.000 habitantes semestrais e sua relação com as campanhas de vacinação em massa com a vacina Sabin). 


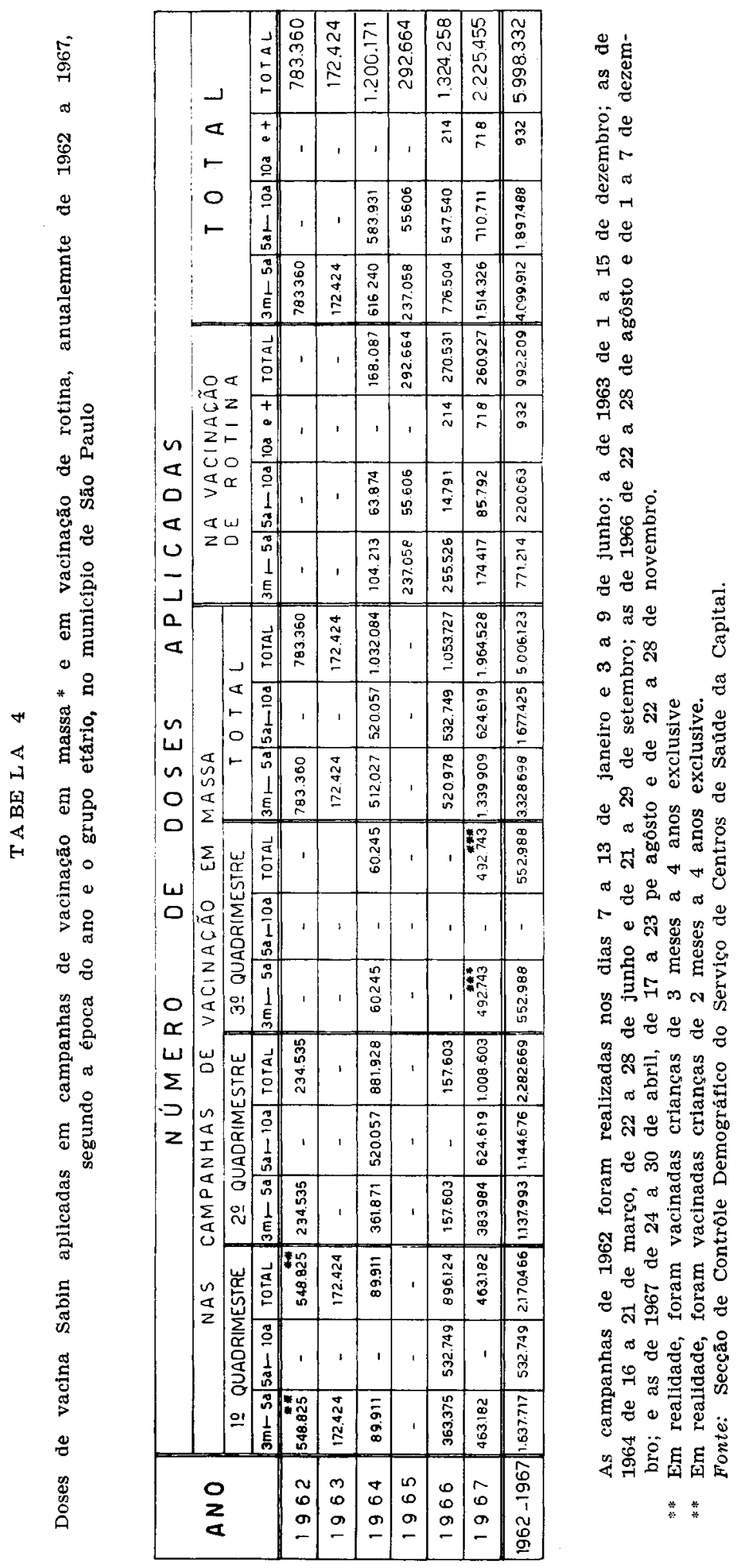


BARBosA, V. - Estado atual do problema da poliomielite no municipio de sáo Paulo. Rev. Saúde puibl., S. Paulo, z(1) :68-80, jun. 1968.

As reduçōes observadas nos coeficientes de 1961 e de 1962 podem ser, respectivamente, explicadas pelo esgotamento parcial natural dos suscetíveis à doença durante a epidemia de 1960 e pela diminuição artificial do número de suscetíveis à virose determinada pelas 783.360 doses de vacina Sabin aplicadas na Capital em 1962 (Tabela 4).

A morbidade por poliomielite em 1962, entre nós, em decorrência dêste último fato, passou a ser de 4,4 por 100.000 habitantes, conforme podemos verificar na Tabela 1 e na Figura 1 . Por conseguinte, apesar da intensa vacinação antipoliomielítica realizada nesse ano ter determinado, sem dúvida, acentuada redução da incidência da moléstia, esta última ainda se mantinha em sua fase potencialmente epidêmica. Se assim não o fôsse, aquiêle valor deveria ter sido inferior a 3 casos por 100.000 habitantes, a se julgar do que dissemos antes sôbre o nivel de transição da poliomielite endêmica para a potencialmente epidêmica, e vice-versa.

Isto, mais o fato de que a mortalidade infantil, nessa época, ainda se mantinha abaixo de 75 óbitos de infantes por 1.000 nascidos vivos (Fig. 1), estava, efetivamente, a indicar que as condições da estrutura epidemiológica da Capital ainda se mostravam favoráveis ao aumento da frequiência e à ocorrência de surtos epidêmicos da doença. Portanto, - problema ainda não se encontrava completamente resolvido. Era preciso, para que isto viesse a ocorrer que, subseqüentemente e o quanto antes, outras campanhas de vacinação em massa fôssem feitas, visando a introdução naquela estrutura de novos bolsōes de imunes que, tornando esta última imprópria ao aparecimento de casos da doença, determinassem o retôrno da poliomielite à sua fase endêmica.

Entretanto, tal não foi feito. Fugiu-se ao esquema de imunização em massa completo contra a poliomielite, antes apresentado na Tabela 3. E, dêsse modo, foi seguramente permitida a acumulação de grande número de novos suscetíveis à moléstia na Capital durante 18 meses, ou seja, até dezembro de 1963, quando foi realizada a terceira campanha de vacinação em massa antipoliomielítica entre nós (Tabela 4). Como resultado, a morbidade por poliomielite paralítica sofreu progressiva e acentuada elevação nos coeficientes semestrais de 1963 (Fig. 2) que, para todo êste ano, atingiụ o alto valor de 11,9 por 100.000 habitantes, pràticamente semelhante ao do ano de 1961 (Tabela 1 e Fig. 1).

Urgia, portanto, que as nossas autoridades, nessa época, começassem tudo de nôvo, no que tangia ao combate da doença por meio da administração em massa da vacina Sabin, em nossa Capital. Elas, nos começos de 1964, se encontravam, outra vez, no marco inicial de combate à poliomielite. Elas precisavam, com efeito, à vista dos resultados antes apontados, iniciar uma segunda fase de luta contra a virose pois, na primeira fase, apesar de seu promissor início, não tinham podido atingir o objetivo almejado: o contrôle da poliomielite no município de São Paulo.

Esta segunda fase de ataque ao problema da poliomielite no município de São Paulo, com efeito, foi iniciada com a campanha de vacinação em massa do mês de dezembro de 1963 , quando foram aplicadas 172.424 doses da vacina Sabin nas crianças de 3 meses a 4 anos inclusive (Fig. 2 e Tabela 4). Posteriormente, outras três campanhas de vacinação em massa foram realizadas nos meses de março, junho e setembro de 1964, num total de 1.032.084 doses nas idades de 3 meses a 9 anos inclusive, das quais 512.027 nas crianças de 3 meses a 5 anos incompletos e 520.057 nas de 5 anos a 10 anos incompletos (Tabela 4). No ano de 1964, quando foi introduzida entre nós a aplicação diária e rotineira da vacina Sabin pelas unidades sanitárias da Capital, foram aplicadas também, dessa maneira, mais 
BARBosa, V. - Estado atual do problema da poliomielite no município de são Paulo. Rev. Saúde públ., S. Paulo, 2(1):68-80, Jun. 1968.

168.087 doses da vacina em tela (Tabela 4).

Como resultado do exposto no parágrafo anterior verificou-se, como era de se esperar, razoável redução da morbidade por poliomielite na Capital, igual a $36,7 \%$ em relação ao valor da de 1963 , visto que o valor do coeficiente dêste último ano - 11,9 - baixou, em 1964, para 7,5 por 100.000 habitantes (Tabela 1 e Fig. 1). Este último valor, como nos é dado ver na Figura 2, foi atingido através da redução progressiva da incidência da doença nos dois semestres do ano em aprêço. Mas, a redução alcançada, talvez devida ao número relativamente pequeno de doses da vacina aplicadas em três das quatro campanhas nesse período realizadas (Tabela 4), não foi suficiente para fazer com que a doença tivesse retornado para a sua fase endêmica, ou seja, que tivesse apresentado para valor de sua incidência em 1964, para cada 100.000 habitantes, menos de 3 casos (Fig. 1).

Assim sendo, a despeito da melhoria observada nesse ano no que diz respeito à ocorrência da virose entre nós, não tínhamos conseguido, ainda, colocá-la sob contrôle. Ela continuava em sua fase potencialmente epidêmica, sendo necessário persistir nas campanhas de vacinação em massa no ano de 1965, procurando-se vacinar intensivamente em cada uma delas, para, completando-se assim a fase de ataque ao problema da poliomielite na Capital, iniciada em dezembro de 1963, podermos chegar ao ano de $1966 \mathrm{com}$ a doença sob contrôle. $\mathbf{E}$ de se notar que, como refôrço à possibilidade de concretização dêste objetivo, às vacinas assim aplicadas poderiam ter sido adicionadas as realizadas de rotina e diàriamente pelas nossas unidades sanitárias.

Acontece porém que, conforme podemos observar na Tabela 4 e na Figura 2, tal não foi feito. Muito pelo contrário, não se efetuou em 1965, na Capital, nenhuma campanha de imunização em massa antipoliomielítica. Apenas, na ver- dade, intensificou-se a vacinação diária e de rotina feita pelas nossas unidades sanitárias. Com isso, a incidência da doença, nesse ano, quando comparada a do de 1964, pràticamente permaneceu a mesma (Fig. 1). O problema da poliomielite entre nós não melhorou $\mathrm{e}$ nem piorou; apenas se manteve no mesmo nível anterior. Isto quer dizer que a nossa Capital, infelizmente, ainda se encontrava a braços com a poliomielite potencialmente epidêmica, e de todos os seus perigos, nessa época.

Essa conduta, embora não totalmente adequada, devido ao que acabamos de dizer, teve porém uma vantagem. E que ela nos permitiu verificar na prática a possibilidade de, sòmente pela imunização da vacinação diária e rotineira feita pelas unidades sanitárias, se manter o nível de incidência anterior da poliomielite na Capital. Ora, se isso ocorreu em um ano - 1965 - em que, como dissemos, a doença se encontrava ainda em sua fase potencialmente epidêmica, é eviden. te que tal viesse a se dar, com muito maior razão, quando a doença já se encontrasse controlada entre nós. A explicação para isto é simples: trata-se de uma questão de probabilidade maior ou menor de ocorrerem casos da doença, em função da proporção de imunes e suscetíveis em nossa comunidade condicionada pela vacinação, independentemente de outros fatôres locais - densidade demográfica, quantidade de vírus circulante, condições de saneamento do meio, etc. que, como sabemos, também influenciam a incidência da virose.

Portanto, quer nos parecer que a não realização, em 1965, das campanhas de vacinação em massa que ainda se faziam necessárias, e sua simples substituição pela vacinação diária intensificada, numa época em que tal ainda não se encontrava indicado, determinou sensivel hiato na segunda fase de ataque contra a poliomielite - iniciada, como vimos, em 1963 - o qual, sem dúvida, foi o responsável pelo fato de que não tínhamos 
BARBosa, V. - Estado atual do problema da poliomielite no município de São Paulo. Rev. Saúde puibl., S. Paulo, 2(1):68-80, jun. 1968.

conseguido controlar a doença ao entrarmos no ano de 1966.

Realmente, a poliomielite nessa época continuava incidindo na base de 7,4 casos por 100.000 habitantes (Tabela $1 \mathrm{e}$ Fig. 1). Em outras palavras, sua incidência, aliada ao fato de que a mortalidade infantil entre nós, então, continuava abaixo de 75 óbitos de infantes por 1.000 nascidos (Fig. 1), colocava-a novamente em evidência como problema sanitário a exigir, para a sua solução, segundo Moraes ${ }^{2}$ (1960), novas campanhas de imunização em massa pela vacina Sabin. Mais uma vez, portanto, viam-se as nossas autoridades sanitárias impelidas a começarem, pràticamente, tudo de nôvo no concernente à luta antipoliomielítica na nossa Capital. Novamente viram-se os nossos sanitaristas passando uma esponja no que foi feito no passado $e$, portanto, partindo mais uma vez do marco zero ou inicial na luta contra a doença, a encetar uma terceira fase de ataque na esperança de que, dessa vez, viessem efetivamente a conseguir o seu contrôle.

Felizmente, e hoje já o podemos assim dizer, em agôsto de 1966 teve início essa fase áurea, digamos assim, da luta contra a poliomielite no município de São Paulo. Áurea porque, graças às suas características básicas - elevada quantidade de doses vacinais administradas, escôlha adequada da época e dos intervalos das campanhas em massa de vacinação realizadas, e indicação correta dos grupos etários que receberam a vacina - permitiu às nossas autoridades, ao se iniciar o ano de 1968, considerar a poliomielite controlada entre nós.

Por conseguinte, deu-se assim, nessa época, o encerramento - tão procurado desde 1962 - do ciclo das campanhas de vacinação em massa antipoliomielítica com a vacina Sabin na Capital. Teve início, por outro lado, a libertação das nossas crianças do perigo representado pela poliomielite em fase epidemiológica potencialmente epidêmica e, também, a necessidade da instalação de um nôvo ciclo no combate à doença - o da manutenção permanente do seu contrôle -. a fim de que, de futuro, possam as nossas crianças continuarem livres da doença e, òbviamente, de tôdas as suas conseqüências.

De fato, em agôsto de 1966 foi realizada uma campanha de vacinação em massa contra a poliomielite no município de São Paulo, cobrindo as idades de 3 meses a 9 anos inclusive, durante a qual foram aplicadas 896.124 doses da vacina Sabin. Seguiram-se-lhe quatro outras campanhas de imunização em massa nos meses de dezembro de 1966 e de abril, agôsto e novembro de 1967; nas duas primeiras e na última foram vacinadas as crianças de 3 meses a 4 anos inclusive $e$, na terceira, as de 3 meses a 9 anos inclusive (Tabela 4).

Nestas quatro campanhas, conforme podemos verificar na Tabela 4 , foram aplicadas 2.122.131 doses da vacina de vírus vivos atenuados. Esta quantidade, somada ao total de doses aplicadas na campanha de agôsto de 1966, perfazem a elevadíssima cifra de 3.018.255 doses, correspondente a aproximadamente $60 \%$ das 5.006.123 doses da vacina dadas nas 11 campanhas de imunização em massa contra a doença efetuadas na Capital, no período de 1962 e 1967. Traduz aquela cifra, por outro lado, a aplicação entre nós, nos anos de 1966 e 1967, e através de campanhas em massa sòmente de uma quantidade de vacinas Sabin muito maior do que as administradas nas primeira e segunda fases da luta contra a doença, respectivamente iguais a 783-360 e 1.204.508 doses (Tabela 4).

Mas, não foram sòmente estas duas características fundamentais das campanhas de vacinação em massa, realizadas em 1966 e 1967, no município de São Paulo, que acabamos de apontar, as únicas responsáveis pelo contrôle da paralisia infantil nessa época. Outra característica fundamental dessas campanhas, de igual valor, deve ser lembrada. Trata-se, como 
BARBOSA, V. - Estado atual do problema da poliomielite no município de São Paulo. Rev. Saude públ., S. Paulo, 2(1):68-80, jun. 1968.

já dissemos, do rigor técnico com que foram observados os intervalos de tempo entre elas pois, todos êles giraram em tôrno de quatro meses de acôrdo com o estabelecido pelo esquema de imunização em massa contra a poliomielite, teòricamente correto, apresentado na Tabela 3 .

Graças a essas características, é bom repisar que essas campanhas realizadas no biênio 1966-1967 puderam, sem dúvida, conduzir as nossas autoridades ao contrôle da doença ao se findar o ano de 1967. Comprovam sobejamente êste fato as considerações que apresentaremos em seguida - baseadas na análise das Figuras 1 e 2 - sôbre a incidência da poliomielite no município de São Paulo, após o ano de 1965. Se não, vejamos.

Em 1966, a morbidade por poliomie. lite na Capital mostrou-se bem menor do que a do ano de 1965 (Fig. 1). Houve, com efeito, uma redução de $41,9 \%$, traduzida pelo fato de que o coeficiente de 7,4 do ano de 1965 baixou, em 1966, para 4,3 (Tabela 1). Esta redução resultou, sem dúvida, da progressiva queda observada nos coeficientes dos primeiro e segundo semestres de 1966, sobretudo no dêste último que, pràticamente, se situou em nível semelhante ao do coeficiente do segundo semestre de 1962 (Fig. 2).

Isto quer dizer que no final do ano de 1966, a exemplo do ocorrido em fins de 1962, as condições da estrutura epidemiológica da Capital, em virtude dos bolsôes de imunes nela introduzidos pela vacinação em massa então efetuadas, mostravam-se novamente eminentemente favoráveis ao contrôle da poliomielite entre nós. Mas, êste último objetivo, como também já acontecera em 1962, ainda não tinha sido atingido. Indicava-o o fato de que a morbidade em 1966 - 4,3 por 100.000 habitantes - ainda se encontrava acima do valor limite $-3 \mathrm{ca}$ sos por 100.000 habitantes - abaixo do qual, como vimos, se teria consumado o retôrno da doença à sua fase endêmica e, por conseguinte, em outras palavras, se teria obtido o seu contrôle. Era preciso, pois, que em 1967 novas campanhas de vacinação em massa fôssem efetuadas até que aquêle contrôle fôsse conseguido.

Diante disso, o Govêrno do Estado de São Paulo, através da Secretaria da Saúde Pública, planejou e executou, como vimos, três campanhas de vacinação em massa com a vacina de vírus vivos atenuados na Capital em 1967, nos meses de abril, agôsto e novembro (Tabela 4). Ao todo, foram aplicadas 1.964 .528 doses da vacina Sabin, número êste bastante expressivo no sentido de atestar o sucesso absoluto das mesmas, no que tange à intensidade com que foram vacinadas, nesse ano, as crianças do nosso município. Sucesso, sem dúvida, em dois sentidos: a) quanto ao número absoluto de vacinas aplicadas nesse ano, face à demanda condicionada pela carga de suscetíveis à doença existente na Capital; b) quanto ao número relativo de vacinas aplicadas em 1967, em comparação com o número de vacinas administradas em 1964 e 1966, anos em que, conforme podemos verificar na Tabela 4 , mais se tinha vacinado contra a doença em nossa comunidade.

Realmente, a quantidade de vacinas administradas nas três campanhas em massa de 1967, que representou aproximadamente $40 \%$ das $\mathbf{5 . 0 0 6 . 1 2 3}$ doses aplicadas nas 11 campanhas efetuadas de 1962 a 1967, comparada às correspondentes aplicadas nos anos de 1964 e de 1966 mostrou-se, num e noutro caso, aproximadamente, duas vêzes maior. Isto equivale a dizer, se assim o quisermos, que no ano de 1967 o número de crianças vacinadas foi pràticamente igual ao número obtido pela soma das vacinas aplicadas em 1964 e em 1966 (Tabela 4).

E o que ocorreu com a incidência da poliomielite paralítica no município de São Paulo em 1967, como conseqüência do elevadíssimo número de vacinas Sabin nesse ano aplicadas, confirmou "in totum" 
BARBosa, V. - Estado atual do problema da poliomielite no municipio de São Paulo. Rev. Saude pribl., S. Paulo, 2(1):68-80, jun. 1968.

a expectativa de nossas autoridades quanto a possibilidade de se conseguir o contrôle da doença entre nós, através de três campanhas de vacinação em massa adequada $e$ intensivamente executadas no ano em aprêço. Realmente, nos albores de 1968 o contrôle da poliomielite em nossa comunidade pôde ser anunciado, de conformidade com o que podemos verificar nas Figuras 1 e 2, como se segue.

$\mathrm{Na}$ Figura 1 destaca-se claramente, após 12 anos em que esteve grassando epidêmicamente, o retôrno da poliomielite à sua fase endêmica no município de São Paulo em 1967, quando o seu coeficiente de morbidade foi de 0,6 por 100.000 habitantes. Isto deveu-se ao fato de que em 1967 ocorreram apenas 32 casos de poliomielite paralítica na nossa Capital, dos quais 16 no primeiro semestre e 16 na segunda metade do ano em tela (Tabela 5). Enquanto isso, no ano anterior, conforme a mesma tabela nos mostra, ocorreram 223 casos da forma paralítica da doença, cabendo 160 ao primeiro semestre e 63 aos últimos seis meses dêsse ano. Conseqüentemente, a redução progressiva que já se fazia presente nos coeficientes semestrais da morbidade por poliomielite em 1966 foi mantida, e de maneira bem mais acentuada, nos correspondentes coeficientes semestrais de 1967 (Fig. 2), o que acabou por determinar, sem dúvida, para êste último ano, o baixíssimo coeficiente de 0,6 por 100.000 habitantes, apontado linhas atrás. E êste coeficiente, seguramente é suficiente por si só para indicar; sem sombra de dúvida, o contrôle da doença em 1967, como queríamos demonstrar.

De modo algum, porém, podem estas palavras levar os nossos sanitaristas a repousarem sôbre os louros da vitória conquistada. Devem êles, pelo contrário, recordando o acontecido em outras áreas nas quais a poliomielite, após ter sido controlada, recrudesceu em virtude do descaso com que foi encarada a manutenção do seu contrôle, pôr-se em guarda contra a ocorrência desta possibilidade entre nós. E, em assim pensando, cabe a êles, desde já, a missão de planejar a fase de manutenção do contrôle da virose em nossa comunidade, daqui por diante, pela aplicação intensiva e adequada de novas doses da vacina à sua população suscetível (nascidos vivos $\mathrm{e}$ transmigrantes), seja bàsicamente diária e rotineira pelas numerosas unidades sanitárias da Capital, seja suplementarmente, quanto se fizer necessário, através de campanha em massa.

\section{S U M M A R Y}

The problem of poliomyelitis in the county of São Paulo, Brazil, was studied from 1933 to 1967. It emphasizes the

TABELA 5

Casos de poliomielite paralítica notificados, segundo os meses, no Município de São Paulo - 1966 e 1967

\begin{tabular}{l|c|c|c|c|c|c|c|c|c|c|c|c|c}
\hline Anos & J & F & M & A & M & J & J & A & S & O & N & D & Total \\
\hline 1966 & 46 & 39 & 23 & 18 & 25 & 9 & 14 & 16 & 14 & 7 & 6 & 6 & 223 \\
1967 & 5 & 3 & 1 & - & 5 & 2 & 5 & 3 & 1 & 1 & 3 & 3 & 32
\end{tabular}

Fonte: Secção de Epidemiologia e Profilaxia Gerais da Secretaria da Saúde Pública do Estado de São Paulo. 
BARBOSA, V. - Estado atual do problema da poliomielite no município de Säo Paulo. Rev. Saúde públ., S. Paulo, 2(1):68-80, jun. 1968.

period of 1962 to 1967 , when the author analizes the relation between the variation in the incidence of the disease and the mass vaccination campaigns with the live virus vaccine attenuated accomplished at that time. Based on the data presented he concludes that in 1967 , when the morbidity rate by poliomyelitis was 0.6 for 100,000 inhabitantes, it was possible to get the control of that disease in the county of São Paulo.

\section{REFERENCIAS BIBLIOGRAICAS}

1. BARBosa, V. - Contribuição para o conhecimento da epidemiologia da polfomielite no municipio de São Paulo. São
Paulo, 1963. (Tese de Doutoramento Fac. Hig. Saúde Públ. USP).

2. MORAES, N. L. de A, - Vacinação contra a poliomielite: diretrizes para uma campanha em massa em comunidades brasileiras. Rev. Serv. Saúde Públ., 11 (1) :165-174, jun. 1960.

3. PAUL, J R. - Endemic and epidemic trends of poliomyelitis in Central and South America. Bull. Wld. Hlth Org., $19(4)$ : 747-758, 1958.

4. PAYNE, A. M. M. - Poliomyelitis as a world problem. In: INTERNATIONAL POLIOMYELITIS CONFERENCE, 3rd, Rome, 1954. Poliomyelftis: papers and discussions presented... Philadelphia, Pa., Lippincott, c. 1955. p. 393-400. 


\section{E R R A T A}

Rev. Saúde públ., S. Paulo, 2(1), jun. 1968

Página 2, equação da $6^{\mathrm{a}}$ linha: - corrija-se para

$$
f(y / x)=\frac{1}{\sigma \sqrt{2 \pi}}-\quad e^{-\frac{1}{2}\left(\frac{y-a-b x}{\sigma}\right)^{2}} \frac{1}{I(w, x)}
$$

Página 7, $9^{\circ}$ linha: - onde se lê "no caso em aprêço temos truncamento", leia-se, "no caso em aprêço temos duplo truncamento"

Página 9: - na equação matricial $D_{(a ̂, ~}^{b}, \hat{a}_{)}$, não há o sinal de igualdade entre a $2^{\mathrm{a}}$ e a $3^{\mathrm{a}}$ matriz.

Página 71, 1" linha: - onde se lê "duas a quatro semanas" leia-se "dois a quatro meses" 
O arquivo disponível sofreu correções conforme ERRATA publicada no Volume 2 Número 2 da revista. 